\title{
Radioprotective activity of blackcurrant extract evaluated by in vitro micronucleus and gene mutation assays in TK6 human lymphoblastoid cells
}

\author{
Ayumi Yamamoto ${ }^{1 *}$, Tokuhisa Hirouchi ${ }^{2}$, Saori Kawamorita ${ }^{1}$, Kana Nakashima ${ }^{1}$, Atena Sugiyama ${ }^{1}$ and Yoji Kato ${ }^{3}$
}

\begin{abstract}
Introduction: Blackcurrant (Ribs nigrum L.) is a classical fruit that has long been used to prepare juice, jam, liqueur, and sometimes medicines in Europe. Previously, we reported a genome defense effect by the antioxidative activity of several types of blackcurrant extracts (BCEs) in yeast and human cell gene mutation assays. In this study, we determined if BCE exerted radioprotective activity against DNA damage, chromosomal aberration, and gene mutations in the TK6 human lymphoblastoid cell line. We prepared aqueous BCE extracted from mature fruits cultivated in the Aomori Prefecture, Japan.

Findings: In the micronucleus test and TK gene mutation assay, TK6 cells were irradiated with 0, 0.125, 0.250, 0.500, and $1.000 \mathrm{~Gy}$ with or without $1.0 \mathrm{mg} / \mathrm{mL}$ BCE. Intracellular hydrogen peroxide $\left(\mathrm{H}_{2} \mathrm{O}_{2}\right)$ was measured using the fluorescent probe $\mathrm{BES}-\mathrm{H}_{2} \mathrm{O}_{2}-\mathrm{Ac}$. Induction of micronuclei and gene mutations by $\gamma$-irradiation exposure was suppressed in combination with BCE. In addition, BCE reduced intracellular $\mathrm{H}_{2} \mathrm{O}_{2}$ levels caused by $\gamma$-irradiation.
\end{abstract}

Conclusions: Our findings clearly support the genome defense potential of blackcurrant against $y$-induced DNA damage. We postulate that these genome defense activities are related to the antioxidant compounds in blackcurrant.

Keywords: Antigenotoxicity, Antioxidative activity, Genome defense, Radioprotection

\section{Introduction}

Blackcurrant (Ribes nigrum L.) is a classical fruit that has long been used to make prepare juice, jam, liqueur, and sometimes medicines in Europe. Blackcurrant, a low deciduous shrub with dark purple fruits containing high levels of polyphenols including anthocyanins, originated in northern Asia and Europe. Currently, Aomori Prefecture in northeast Japan accounts for approximately $90 \%$ of blackcurrant production in Japan. The beneficial effects of blackcurrant have been reported worldwide [1].

Recently, we reported that extracts of mature and premature blackcurrant produced in Aomori Prefecture had high anti-oxidant and anti-genotoxic activities, as evaluated using a yeast loss-of-heterozygosity $(\mathrm{LOH})$ assay, an in vitro comet assay to evaluate DNA damage, and a

\footnotetext{
* Correspondence: yamamoto-c@hachinohe-ct.ac.jp

${ }^{1}$ Chemical and Biological Engineering Course, Department of Industrial System Engineering, National Institute of Technology, Hachinohe College, 16-1 Uwanotai, Tamonoki, Hachinohe-shi, Aomori-ken 039-1192, Japan

Full list of author information is available at the end of the article
}

micronucleus (MN) test to screen for genotoxic compounds in human TK6 lymphoblastoid cells [2, 3]. In the yeast $\mathrm{LOH}$ assay, blackcurrant extracts (BCEs) extracted from premature and mature fruits suppressed gene mutations induced by hydrogen peroxide $\left(\mathrm{H}_{2} \mathrm{O}_{2}\right)$, methyl methanesulfonate (MMS), and ultraviolet (UV) radiation [2]. The BCEs showed antigenotoxic effects, with or without heat treatment, against $\mathrm{H}_{2} \mathrm{O}_{2}$-induced oxidative stress in human lymphoblastoid cells, as determined using comet and MN assays [3].

Ionizing radiation, which is a major DNA damaging agent emitted from radioactive substances, induces DNA damage such as oxidative damage and double-stranded breaks (DSBs) $[4,5]$. We hypothesized that blackcurrant has the potential to decrease the biological effects of ionizing radiation. To this end, we evaluated the genome defense activity of $\mathrm{BCE}$ as a radioprotective agent using a human lymphoblastoid cell line. 


\section{Material and Methods \\ Cell culture}

The TK6 human lymphoblastoid cell line was grown in RPMI 1640 medium (Nakalai Tesque, Kyoto, Japan) supplemented with $100 \mathrm{U} / \mathrm{mL}$ penicillin, $100 \mu \mathrm{g} / \mathrm{mL}$ streptomycin, $0.25 \mu \mathrm{g} / \mathrm{mL}$ amphotericin $\mathrm{B}, 10 \%$ heat-inactivated fetal bovine serum, and $200 \mu \mathrm{g} / \mathrm{mL}$ sodium pyruvate [6]. The cells were incubated at $37{ }^{\circ} \mathrm{C}$ in a $5 \% \mathrm{CO}_{2}$ atmosphere with $100 \%$ humidity.

\section{Chemicals}

Trifluorothymidine (TFT) was purchased from Sigma Chemical Company (St. Louis, MO, USA). BES- $\mathrm{H}_{2} \mathrm{O}_{2}$ Ac was purchased from Wako Pure Chemical Industries (Osaka, Japan).

\section{Irradiation}

$\gamma$-irradiation was performed using a Pantak HF-320 machine (PANTAK Ltd., East Haven, CT, USA) at $200 \mathrm{kV}$, $20 \mathrm{~mA}$, and a dose rate of $1.0 \mathrm{~Gy} / \mathrm{min}$.

\section{BCE preparation}

Mature blackcurrant fruits, provided from Aomori Blackcurrant Association, Japan, were frozen and preserved until use. The frozen fruit was thawed and mixed with deionized distilled water (DDW) to prepare juice including the soluble components. This blackcurrant solution was sterilized by filtration using the Filtermax rapid vacuum filtration with a $0.22 \mu \mathrm{m}$ pore size (TPP Techno Plastic Products AG, Trasadingen, Switzerland). After filter sterilization, the solution was freeze-dried and the resulting material was dissolved in DDW at a concentration of $100 \mathrm{mg} / \mathrm{mL}$.

\section{Combined $\mathrm{\gamma}$-irradiation exposure and BCE treatment}

TK6 was exposed to $\gamma$-irradiation at doses of $0.125,0.250$, 0.500 , and 1.000 Gy with or without $1.0 \mathrm{mg} / \mathrm{mL} \mathrm{BCE,} \mathrm{a}$ concentration that was decided in accordance with a previous study [3]. The dose rate was $1.0 \mathrm{~Gy} / \mathrm{min}$ (Fig. 1).

\section{Genotoxicity assays}

Cells exposed to $\gamma$-irradiation with or without BCE were incubated for 3 days at $37{ }^{\circ} \mathrm{C}$ (Fig. 1), and subsequently collected by centrifugation. TK gene mutation and cytotoxicity assays were performed according to published methods $[6,7]$. In the TK gene mutation assay, TK6 cells were plated at a density of 40,000 cells/well with $3.0 \mu \mathrm{g} / \mathrm{mL}$ TFT. In the cytotoxicity assay, cells were immediately seeded at a density of 1.6 cells/well in 96-well plates after irradiation with or without BCE. All plates were incubated at $37{ }^{\circ} \mathrm{C}$ in a humidified atmosphere of $5 \% \mathrm{CO}_{2}$. Normal-growing (NG) colonies after incubation for 2 weeks and slow-growing (SG) colonies after incubation for 4 weeks were counted on the mutation assay plates containing TFT. The MN assay was performed as previously described $[3,7,8]$. Briefly, after $48 \mathrm{~h}$ of irradiation, approximately $10^{6}$ cells were suspended in $0.075 \mathrm{M}$ potassium chloride and then incubated for $10 \mathrm{~min}$ at room temperature. The suspended cells were fixed in ice-cold methanol containing $25 \%$ acetic acid, followed by centrifugation, re-suspension in ice-cold methanol containing $25 \%$ acetic acid, and suspension in ice-cold methanol containing $1.0 \%$ acetic acid. A drop of fixing cell solution was spotted onto glass slides, which were then air-dried. The fixed cells were stained with acridine orange (Wako Pure Chemical Industries) and analyzed with a fluorescence microscope (Olympus, Tokyo, Japan).

\section{Measurements of intracellular reactive oxygen species}

The levels of intracellular reactive oxygen species (ROS) were measured using $50 \mu \mathrm{M}$ BES- $\mathrm{H}_{2} \mathrm{O}_{2}$-Ac fluorescence probe purchased from Wako Pure Chemical Industries. Then $5 \times 10^{5}$ cells $/ \mathrm{mL}$ of TK6 cells were incubated with BES- $\mathrm{H}_{2} \mathrm{O}_{2}-\mathrm{Ac}$ for $1 \mathrm{~h}$. After washing with phosphatebuffered saline, TK6 cells were exposed to $\gamma$-irradiation with or without BCE. More then 100 cells were counted to estimate the percentage of ROS-positive cells. The increase in the proportion of fluorescent cells was calculated by comparison with control cells, which lacked $\mathrm{BCE}$ treatment and $\gamma$-irradiation.

\section{Statistical analysis}

For all of the assays, statistical analyses were performed using the Student's $t$-test. The standard deviation was calculated from three separate experiments. Data analyses were performed with Microsoft Excel 2016 software (Microsoft, Redmond, WA, USA).

\section{Results}

Inhibition of $\gamma$-irradiation-induced $\mathrm{MN}$ formation by treatment of TK6 cells with BCE

Treatment with $\gamma$-irradiation alone increased the frequency of $\mathrm{MN}$ formation, determined $\mathrm{y}$ an increase in the number of cells with MN per 1000 TK6 cells (Fig. 2). The $\gamma$-irradiated cells showed significantly higher $\mathrm{MN}$ frequencies than non-irradiated cells without $\mathrm{BCE}$ treatment. With combined treatment, $\mathrm{MN}$ frequencies were significantly decreased when the cells were treated with $1.0 \mathrm{mg} / \mathrm{mL}$ BCE at $\gamma$-irradiation doses of 0.125 , $0.250,0.500$, and 1.000 Gy $(p<0.05, p<0.05, p<0.1$, and $p<0.05$, respectively). In addition, with $1.0 \mathrm{mg} / \mathrm{mL}$ BCE, decreases in $\mathrm{MN}$ by $12 \pm 13 \%, 24 \pm 16 \%, 32 \pm 8 \%$, $32 \pm 15 \%$, and $40 \pm 13 \%$ were obtained at $\gamma$-irradiation doses of $0.125,0.250,0.500$, and $1.000 \mathrm{~Gy}$, respectively. These results suggest that treatment with $1.0 \mathrm{mg} / \mathrm{mL}$ BCE exerts suppressive effects on $\gamma$-induced $\mathrm{MN}$ formation in TK6 cells. 


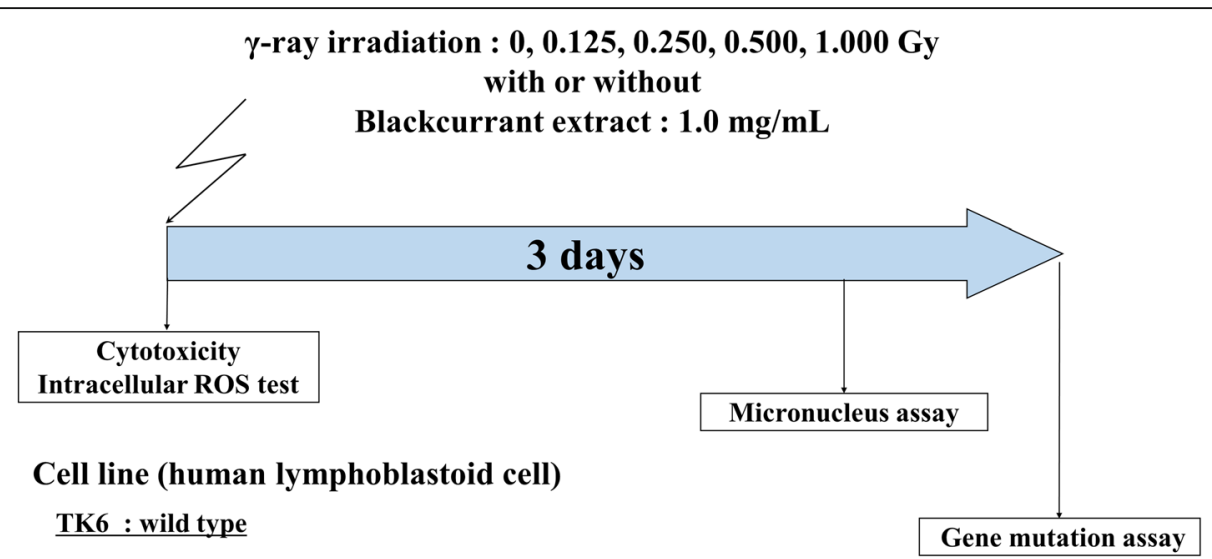

Fig. 1 An experimental design to elucidate the combined effects of $y$-irradiation and BCE treatment. The TK6 cells were exposed to 0, 0.125, 0.250, 0.500, or 1.000 Gy with or without $1.0 \mathrm{mg} / \mathrm{mL}$ BCE. After treatment, cells were immediately subjected to cytotoxicity and intracellular ROS tests. For the MN assay, cells were collected 2 days after treatment. For the gene mutation assay, cells were collected 3 days after the treatment

Suppressive effects of cytotoxicity and mutagenicity of $\gamma$-irradiation with combined treatment of BCE and $\mathrm{Y}$-irradiation in TK6 cells

Exposure of TK6 cells to $\gamma$-irradiation without BCE treatment at doses of $0.125,0.250,0.500$, and 1.000 Gy resulted in 95.4\%, 71.1\% ( $p<0.01), 48.3 \%$ $(p<0.01)$, and $20.8 \%(p<0.01)$ cell survival, respectively (Fig. 3). Cell survival decreased with $\gamma$-irradiation. The survival of TK6 cells treated with BCE at radiation doses of 0.000 and 1.000 Gy was significantly higher than that of cells without BCE treatment $(p<0.01)$. These results suggest that the combined treatment of $\mathrm{BCE}$ at a concentration of $1.0 \mathrm{mg} / \mathrm{mL}$ exerts a suppressive effect on the cellkilling effect of $\gamma$-irradiation. TK6 generates two distinct phenotypic classes of TK mutants. NG mutants have the same doubling time as wild-type cells, and the doubling time of SG mutants is longer than that of wild-type and NG mutants. NG mutants contain small DNA mutations such as point mutations, small insertions, and small deletions, whereas SG mutants contain large chromosomal structure changes. In the mutation assay, $\gamma$-irradiation without BCE treatment enhanced NG and SG TK mutation frequencies of TK6 cells with significant differences (Fig. 4, Table 1). $\gamma$-irradiation alone induced total mutations (tNG and SG mutations) at rates of $9.08 \times 10^{-6}, 15.95 \times 10^{-6}$, $34.64 \times 10^{-6}$ and $35.74 \times 10^{-6}$ TK6 cells exposed to $0.125,0.250,5.000$, and 1.000 Gy, respectively $(p<0.05, p<0.05, p<0.01$, and $p<0.01$, respectively). In the combination treatment with $1.0 \mathrm{mg} / \mathrm{mL}$ BCE and $\gamma$-irradiation, total mutation frequencies decreased when the cells were treated with $1.0 \mathrm{mg} / \mathrm{mL}$ BCE at all four doses $(p<0.1, p<0.05, p<0.1$, and $p<0.05$, respectively). The combined treatment with BCE suppressed NG mutation frequencies at doses of

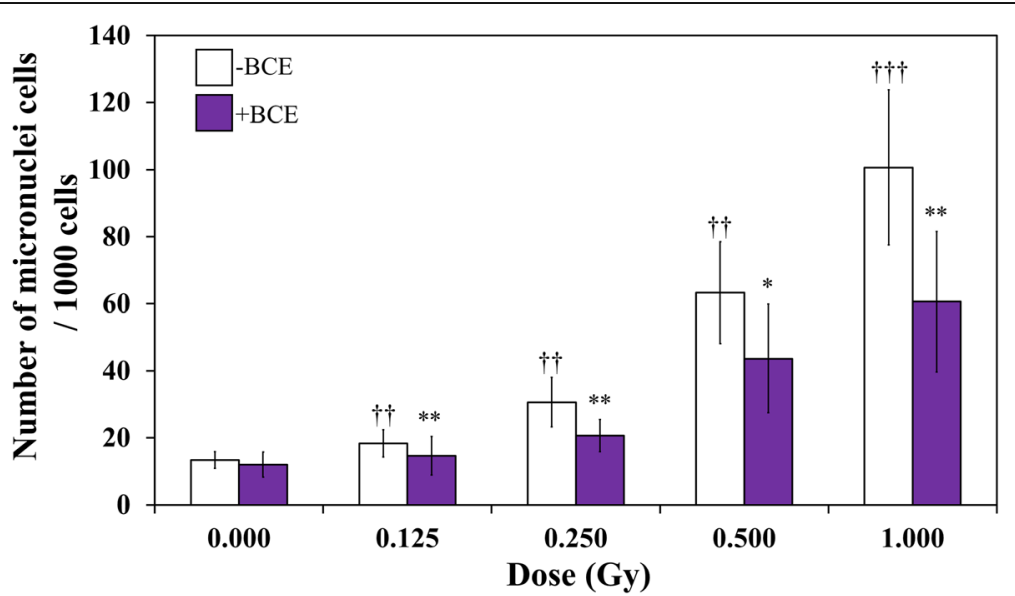

Fig. 2 MN assay in TK6 cells. Daggers ( $+\dagger$ ) and daggers ( $+\dagger+$ ) denote $p<0.05$ and $p<0.01$, respectively, in the $t$-test comparing control and $y$-irradiated cells. An asterisk $\left(^{*}\right)$ and asterisks $\left(^{* *}\right)$ denote $p<0.1$ and $p<0.05$, respectively, in the $t$-test of comparing BCE-untreated and BCE-treated cells 


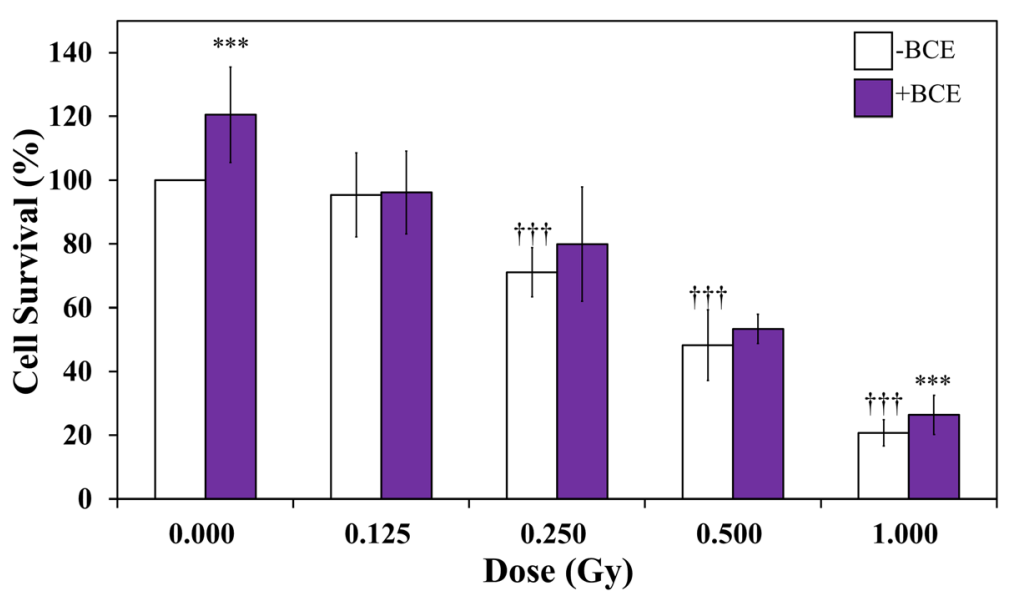

Fig. 3 Effects of irradiation on the survival of TK6 cells. Daggers ( $+\dagger+$ ) denote $p<0.01$ in the $t$-test comparing control and $y$-irradiated cells. Asterisks $\left(^{* *}\right)$ denote $p<0.01$ in the $t$-test comparing BCE-untreated and BCE-treated cells

$0.000,0.125$, and 0.250 Gy with marginal significance $(p<0.1, p<0.1$, and $p<0.1$, respectively). SG mutation frequencies at doses of $0.125,0.250$, and 0.500 Gy were reduced by BCE combination treatment with significant and marginally significant differences $(p<0.1, p<0.1$ and $p<0.05$, respectively). These results suggest that the combined treatment of $\mathrm{BCE}$ and $\gamma$-irradiation exerts a suppressive effect against several types of $\gamma$-induced gene mutations.

\section{Scavenging activity of $\gamma$-induced intracellular ROS by combined treatment with BCE in TK6 cells}

Because our previous study found that BCE has antioxidant activity, we focused on intracellular ROS in BCEtreated TK6. $\mathrm{H}_{2} \mathrm{O}_{2}$ is a marker of oxidative stress and is generated by radiation [9]. Thus, we assayed intracellular $\mathrm{H}_{2} \mathrm{O}_{2}$ levels as an index of ROS to evaluate the scavenging activity of $\mathrm{BCE}$ against $\gamma$-induced ROS using the fluorescent probe BES- $\mathrm{H}_{2} \mathrm{O}_{2}$-Ac, a highly specific $\mathrm{H}_{2} \mathrm{O}_{2}$ indicator. $\gamma$-irradiation induced a higher level of intracellular ROS than nonirradiated cells without BCE treatment (Fig. 5). The increasing rates of $\gamma$-irradiated cells were $1.42 \pm 0.11,1.56 \pm 0.26,1.45 \pm 0.10$, and $1.84 \pm 0.34$ obtained from $0.125,0.250,0.500$, and 1.000 Gy $(p<0.05, p<0.05, p<0.01$, and $p<0.01$, respectively). In contrast, upon combined treatment, the increasing rate of intracellular ROS was $1.01 \pm 0.10$, $1.12 \pm 0.11,1.11 \pm 0.12,1.02 \pm 0.08$, and $0.99 \pm 0.30$ for the same $\gamma$-irradiation doses. There were significant differences between BCE-untreated and BCE-treated cells. The $p$ values of the TK6 cells $\gamma$-irradiated at 0.125 , $0.250,0.500$, and 1.000 Gy were $p<0.01, p<0.05$, $p<0.05$, and $p<0.05$, respectively. BCE-treated cells suppressed the intracellular ROS induced by $\gamma$-irradiation with significant differences from untreated cells.
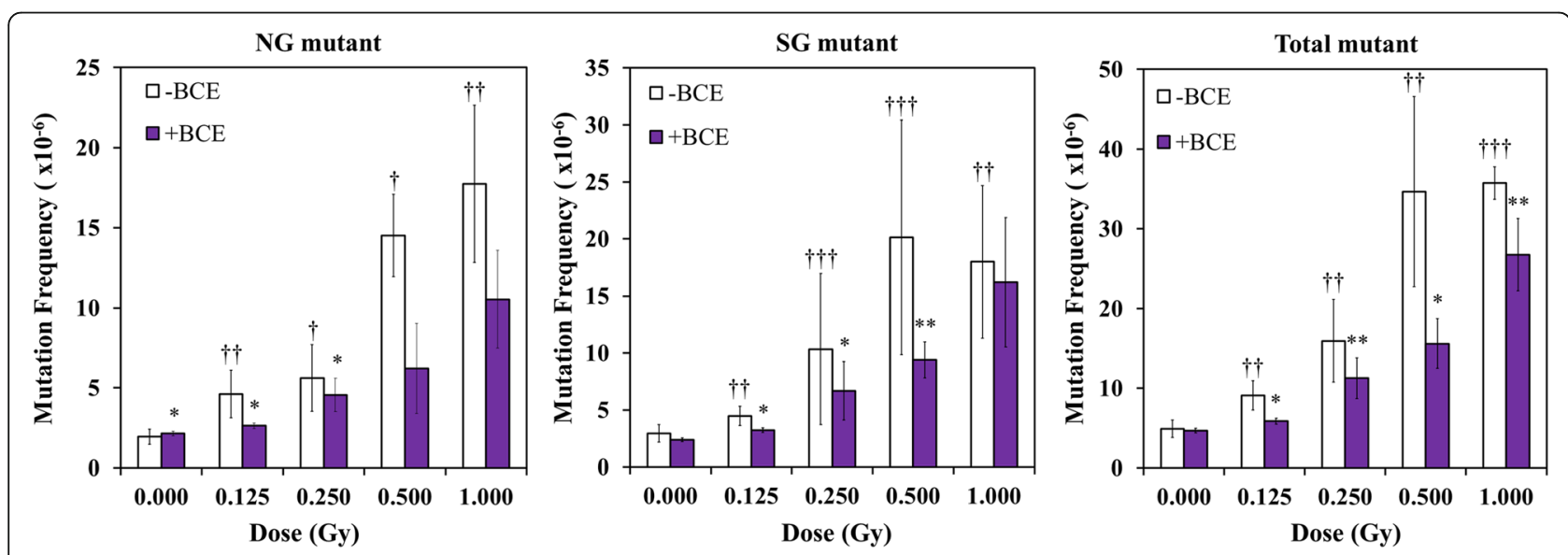

Fig. 4 TK gene mutation assay in TK6 cells. Daggers (†+) and daggers (†+†) denote $p<0.05$ and $p<0.01$, respectively, in the $t$-test comparing control and $Y$-irradiated cells. An asterisk $\left({ }^{*}\right)$ and asterisks $\left(^{* *}\right)$ denote $p<0.1$ and $p<0.05$, respectively, in the $t$-test comparing BCE-untreated and BCE-treated cells 
Table 1 Results of TK gene mutation assay in TK6 cells

\begin{tabular}{|c|c|c|c|c|c|}
\hline Irradiation dose (Gy) & 0.000 & 0.125 & 0.250 & 0.500 & 1.000 \\
\hline \multicolumn{6}{|c|}{ Mutant Frequency $\left(\times 10^{-6}\right.$ cells $)$} \\
\hline \multicolumn{6}{|l|}{ BCE untreated } \\
\hline NG mutant & $2.95 \pm 0.76$ & $4.48 \pm 0.84(p<0.05)^{\dagger \dagger}$ & $10.33 \pm 6.62(p<0.1)^{\dagger}$ & $20.13 \pm 10.28(p<0.1)^{\dagger}$ & $18.00 \pm 6.68(p<0.05)^{\dagger \dagger}$ \\
\hline SG mutant & $1.95 \pm 0.470 .47$ & $4.61 \pm 1.48(p<0.05)^{\dagger \dagger}$ & $5.62 \pm 2.09(p<0.01)^{t+\dagger}$ & $14.51 \pm 2.57(p<0.01)^{\dagger+\dagger}$ & $17.74 \pm 4.91(p<0.05)^{\dagger \dagger}$ \\
\hline Total mutant & $4.90 \pm 1.07$ & $9.08 \pm 1.84(p<0.05)^{\dagger \dagger}$ & $15.95 \pm 5.21(p<0.05)^{t+}$ & $34.64 \pm 11.94(p<0.05)^{\dagger+}$ & $35.74 \pm 2.04(p<0.01)^{t+\dagger}$ \\
\hline \multicolumn{6}{|l|}{$\mathrm{BCE}$ treated } \\
\hline NG mutant & $2.38 \pm 0.15$ & $3.22 \pm 0.21(p<0.1)^{*}$ & $6.69 \pm 2.57(p<0.1)^{*}$ & $9.40 \pm 1.59$ & $16.20 \pm 5.67$ \\
\hline SG mutant & $2.14 \pm 0.13$ & $2.63 \pm 0.17(p<0.1)^{*}$ & $4.56 \pm 1.04(p<0.1)^{*}$ & $6.21 \pm 2.82(p<0.05)^{* *}$ & $10.54 \pm 3.05$ \\
\hline Total mutant & $4.68 \pm 0.27$ & $5.85 \pm 0.38(p<0.1)^{*}$ & $11.25 \pm 2.58(p<0.05)^{* *}$ & $15.61 \pm 3.13(p<0.1)^{*}$ & $26.74 \pm 4.55(p<0.05)^{* *}$ \\
\hline
\end{tabular}

Dagger $^{\dagger}$, daggers ${ }^{\dagger+}$ and daggers ${ }^{\dagger+\dagger}$ denote $p<0.1, p<0.05$ and $p<0.01$, respectively, in the $t$-test comparing non-irradiated and $\gamma^{\text {-irradiated cells. An asterisk }}{ }^{*}$ and asterisks" ${ }^{*}$ denote $p<0.1$ and $p<0.05$, respectively, in the $t$-test of comparing BCE-untreated and BCE-treated cells

\section{Discussion}

Our observations that BCE suppressed not only radiation-induced $\mathrm{MN}$ and gene mutations but also radiation-induced intracellular $\mathrm{ROS}$ indicate that $\mathrm{BCE}$ has radioprotective activity.

Radiation induces DSBs in DNA, which result in chromosomal aberrations and cell death, generating a wide variety of ROS that induce gene mutations following the occurrence of oxidative bases in DNA [10]. The production of DSBs in DNA activates DNA damage checkpoint signaling and DNA repair pathways, which employ nonhomologous end joining (NHEJ) and homologous recombination (HR) [11]. In contrast, ionizing radiation induces ROS including superoxide anions, hydrogen peroxide, and hydroxyl radicals [12]. These ROS damage several kinds of biomolecules including DNA, proteins, and lipids [13]. ROS is scavenged by superoxide dismutase and catalase $[13,14]$. Oxidative nucleotides such as 8hydroxyguanosine (8-oxodG, 8OHdG, and 8OHG) are mutagenic lesions that are formed by ROS in the nucleotide pool as well as in DNA [15-18].

Previously, we reported the antigenotoxic effects of BCE evaluated using yeast $\mathrm{LOH}$ assay and human lymphoblastoid cell assays [2, 3]. In a yeast gene mutation assay, BCEs from premature and mature fruit, inhibited DNA mutations induced by $\mathrm{H}_{2} \mathrm{O}_{2}$, methyl MMS as an alkylating agent, and UV as physical stress [2]. Several types of BCEs extracted from mature and premature fruit with or without heat treatment exhibited antigenotoxic and antioxidative activities against $\mathrm{H}_{2} \mathrm{O}_{2}$-induced DNA damage and intracellular ROS in TK6 cells [3]. BCE contains high concentrations of polyphenolic compound, including anthocyanin, and of L-ascorbic (vitamin C) acid, which exerts antioxidant activity with radical scavenging $[2,3]$. We evaluated the radical scavenging activity of polyphenolic compounds such as anthocyanins and catechin. BCE-containing anthocyanins and vitamin $\mathrm{C}$ induce small structural changes in erythrocyte membranes that exert

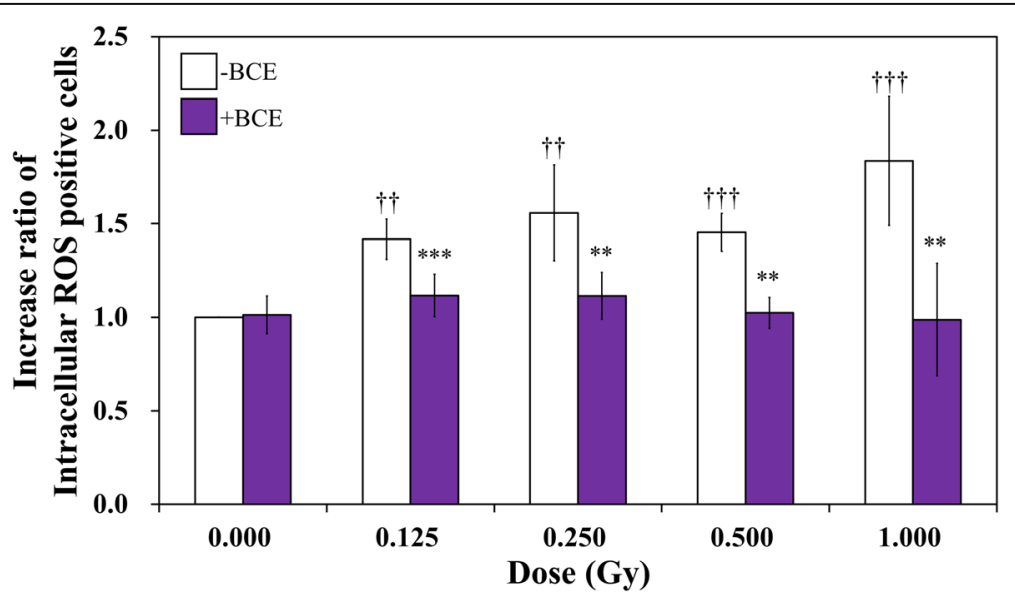

Fig. 5 Intracellular ROS $\left(\mathrm{H}_{2} \mathrm{O}_{2}\right)$ assay in TK6 cells. Daggers ( ++ ) and daggers ( $\left.++\dagger\right)$ denote $p<0.05$ and $p<0.01$, respectively, in the $t$-test comparing control and $y$-irradiated cells. Asterisks $\left(^{* *}\right)$ and asterisks $\left(^{* *}\right)$ denote $p<0.05$ and $p<0.01$, respectively, in the $t$-test comparing BCE-untreated and treated cells 
beneficial effects on protection against oxidation [19]. There is a possibility that cell membrane modifications were involved in the radioprotective activity of BCE observed in this study.

Recently, Nishimura et al. [20] reported that Actinidia argute, known as sarunashi, has antimutagenic and antioxidant activities. Furthermore, an extract of Barbados cherry fruit containing several antioxidants such as anthocyanin, vitamins $\mathrm{E}$ and $\mathrm{C}$, and $\beta$-carotene showed antimutagenic effects, as measured by a MN test against radioisotope iodine-131, and this antimutagenic activity was mainly associated with the capture of free radicals generated by radiation [21, 22]. Polyphenols showed radioprotective properties associated with their high antioxidant activity in in vitro and in vivo assays [23-29]. Our findings are consistent with those in these reports. Dietary polyphenols and their analogs such as resveratrol, curcumin, quercetin, and catechin may activate the expression of DNA repair proteins such as the NHEJ and $\mathrm{HR}$ proteins Ku70, NBS, Werner helicase, and Nijmegen Breakage Syndrome protein (nibrin) through the promotion of the class III histone deacetylase sirtuin 1 (SIRT1) [30]. SIRT1 is associated with the DNA damage response to $\gamma$-irradiation and is directly associated with DSB repair proteins [31]. An anthocyanin, D3R, upregulated SIRT1 expression in human umbilical vein endothelial cells [32]. In our experiments, micronuclei in the MN test and the SG mutation in the TK gene mutation assay, which are associated with DSBs caused by irradiation, were suppressed by BCE treatment. We speculate that BCE anthocyanins upregulate SIRT1 expression and modify the activity of HR-associated proteins. However, while ROS, micronuclei, and gene mutations induced by $\gamma$ irradiation were strongly inhibited by the combined treatment of BCE and $\gamma$-irradiation, BCE treatment did not cause complete recovery of cell survival. Future studies are needed to clarify the mechanism that underlies this radioprotective effect according to different activities and constituents of polyphenols and other antioxidants, as well as the interaction between these compounds and DNA repair mechanisms. In this study, we treated TK6 cells concurrently with BCE and $\gamma$-irradiation. Thus, future studies should evaluate the optimal timing and best concentration of BCE to use for therapeutic purposes.

In conclusion, we demonstrated that BCE exerted genome defense activities against $\gamma$-irradiation-induced micronuclei, gene mutations, and oxidative stress in the TK6 human lymphoblastoid cell line. Because oxidative stress is one of the major factors in $\gamma$-radiation-induced genome instability, which is associated with carcinogenesis and several diseases, we suggest that BCE activities may protect cells from damage induced by $\gamma$-irradiation. This is the first study to show the radioprotective activity of BCE.

\section{Abbreviations}

BCE: The extract obtained from the fruit of blackcurrant; C3G: Cyanidin 3-O$\beta$-glucoside; C3R: Cyanidin 3-O- $\beta$-rutinoside; D3G: Delphinidin 3-O- $\beta$ glucoside; D3R: Delphinidin 3-O- $\beta$-rutinoside; DDW: Deionized distilled water; DSBs: Double stranded breaks; HDAC: Histone deacetylase; HR: Homologous recombination; LOH: Loss of heterozygosity; MMS: Methylmethanesulfonate; MN: Micronucleus; NG: Normally growing; NHEJ: Nonhomologous end joining; PBS: Phosphate buffered saline; ROS: Reactive oxygen species; SG: Slowly growing; SIRT1: Sirtuin 1; TFT: Trifluorothymidine; UV: Ultraviolet

\section{Acknowledgments}

We thank Dr. Honma (National Institutes of Health Science) for providing the TK6 cells.

\section{Funding \\ This study was financially supported by the JSPS Grant-in-Aid for Young Scientists (B) Grant Number 17 K18317, Grant-in-Aid from the Japan Cassis Association, Grant-in-Aid from National Institute of Technology for Young Scientists, and the Agriculture, Forestry and Fisheries Department of Aomori city.}

Availability of data and materials

All data generated and analyzed during this study are included in this published article.

Authors' contributions

AY, TH, SK, KN, and AS collected the data. AY and YK critically discussed the study. All of the authors have read and approved the final manuscript.

Ethics approval and consent to participate

Not applicable.

Consent for publication

Not applicable.

Competing interests

The authors declare that they have no competing interest.

\section{Publisher's Note}

Springer Nature remains neutral with regard to jurisdictional claims in published maps and institutional affiliations.

\section{Author details}

${ }^{1}$ Chemical and Biological Engineering Course, Department of Industrial System Engineering, National Institute of Technology, Hachinohe College, 16-1 Uwanotai, Tamonoki, Hachinohe-shi, Aomori-ken 039-1192, Japan. ${ }^{2}$ Department of Radiobiology, Institute for Environmental Science, 1-7 lenomae, Obuchi, Rokkasho-mura, Kamikita-gun, Aomori-ken 039-3212, Japan. ${ }^{3}$ Laboratory of Food Science, Faculty of Education, Hirosaki University, 1 Bunkyo-cho, Hirosaki-shi, Aomori-ken 036-8560, Japan.

Received: 2 May 2017 Accepted: 6 July 2017

Published online: 01 September 2017

\section{References}

1. Gopalan A, Reuben SC, Ahmed S, Darvesh AS, Hohmann J, Bishayee A. The health benefits of blackcurrants. Food Funct. 2012;3:795-809.

2. Yamamoto A, Kawaguchi S, Nakashima K, Kamitai Y, Kato Y. The antimutagenic activities of blackcurrant extract: evaluation using Saccharomyces cerevisiae $\mathrm{LOH}$ system. Genes Environ. 2012;34:115-22.

3. Yamamoto A, Nakashima K, Kawamorita S, Sugiyama A, Miura M, Kamitai Y, Kato Y. Protective effects of raw and cooked blackcurrant extract on DNA damage induced by hydrogen peroxide in human lymphoblastoid cells. Pharm Biol. 2014:52:782-8.

4. Reisz JA, Bansal N, Qian J, Zhao W, Furdui CM. Effects of ionizing radiation on biological molecules-mechanisms of damage and emerging methods of detection. Antioxid Redox Signal. 2014;21:260-92.

5. Mahaney BL, Meek K, Lees-Miller SP. Repair of ionizing radiation-induced DNA double-strand breaks by non-homologous end-joining. Biochem J. 2009;417:639-50.

6. Yamamoto A, Sakamoto Y, Masumura K, Honma M, Nohmi T. Involvement of mismatch repair proteins in adaptive responses induced by $\mathrm{N}$-methyl- $\mathrm{N}$ 
'-nitro-N-nitrosoguanidine against $\gamma$-induced genotoxicity in human cells. Mutat Res - Fundam Mol Mech Mutagen. 2011;713:56-63.

7. Scolastici C, Alves de Lima RO, Barbisan LF, ALA F, Ribeiro DA, Salvadori DM. Antigenotoxicity and antimutagenicity of lycopene in HepG2 cell line evaluated by the comet assay and micronucleus test. Toxicol in Vitro. 2008;22:510-4.

8. Hayashi M. The micronucleus test-most widely used in vivo genotoxicity test-. Genes Environ. 2016:38:18.

9. Kang KA, Zhang R, Lee KH, Chae S, Kim BJ, Kwak YS, Park JW, Lee NH, Hyun JW. Protective effect of triphlorethol-A from Ecklonia cava against ionizing radiation in vitro. J Radiat Res. 2006:47:61-8.

10. Georgakilas AG. Processing of DNA damage clusters in human cells: current status of knowledge. Mol BioSyst. 2008;4:30-5.

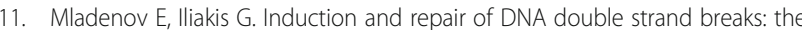
increasing spectrum of non-homologous end joining pathways. Mutat Res. 2011;711:61-72

12. Cadet J, Ravanat JL, TavernaPorro M, Menoni H, Angelov D. Oxidatively generated complex DNA damage: Tandem and clustered lesions. Cancer Lett. 2012;327:5-15.

13. Schieber M, Chandel NS. ROS function in redox signaling and oxidative stress. Curr Biol. 2014;24:453-62.

14. Afonso V, Champy R, Mitrovic D, Collin P, Lomri A. Reactive oxygen species and superoxide dismutases: role in joint diseases. Joint Bone Spine. 2007:74:324-9.

15. Matés JM, Sánchez-Jiménez F. Antioxidant enzymes and their implications in pathophysiologic processes. Front Biosci. 1999:4:D339-45.

16. Klaunig JE, Kamendulis LM, Hocevar BA. Oxidative stress and oxidative damage in carcinogenesis. Toxicol Pathol. 2010;38:96-109.

17. Limoli CL, Giedzinski E, Morgan WF, Swarts SG, Jones GD, Hyun W. Persistent oxidative stress in chromosomally unstable cells. Cancer Res. 2003;63:3107-11.

18. Steinboeck F, Hubmann M, Bogusch A, Dorninger P, Lengheimer T, Heidenreich $E$. The relevance of oxidative stress and cytotoxic DNA lesions for spontaneous mutagenesis in non-replicating yeast cells. Mutat Res Fundam Mol Mech Mutagen. 2010;688:47-52.

19. Bonarska-Kujawa D, Cyboran S, Zyłka R, Oszmiański J, Kleszczyńska H. Biological activity of blackcurrant extracts (Ribes nigrum L.) in relation to erythrocyte membranes. Biomed Res Int. 2014;2014:783059. doi:10.1155/ 2014/783059. Epub 2014 Jan 16

20. Nishimura M, Okimasu Y, Miyake N, Tada M, Hida R, Negishi T, Arimoto-Kobayashi S. Inhibitory effect of Actinidia arguta on mutagenesis, inflammation and two-stage mouse skin tumorigenesis. Genes Environ. 2016;38:25.

21. Diaconeasa Z, Leopold L, Rugină D, Ayvaz H, Socaciu C. Antiproliferative and antioxidant properties of anthocyanin rich extracts from blueberry and blackcurrant juice. Int J Mol Sci. 2015;16:2352-65.

22. Berti AP, Düsman E, Mariucci RG, Lopes NB, Vicentini VE. Antimutagenic and radioprotective activities of beta-carotene against the biological effects of iodine-131 radiopharmaceutical in Wistar rats. Genet Mol Res. 2014;13:2248-58.

23. Almeida IV, Düsman E, Heck MC, Pamphile JA, Lopes NB. Cytotoxic and mutagenic effects of iodine-131 and radioprotection of acerola ( Malpighia glabra L .) and beta-carotene in vitro. Genet Mol Res. 2013;12:6402-13.

24. Jagetia CG. Radioprotective potential of plants and herbs against the effects of ionizing radiation. J Clin Biochem Nutr. 2007;40:74-81.

25. Londhe JS, Devasagayam TP, Foo LY, Ghaskadbi SS. Radioprotective properties of polyphenols from Phyllanthus amarus Linn. J Radiat Res. 2009;50:303-9.

26. Düsman E, Berti AP, Mariucci RG, Lopes NB, Tonin LT, Vicentini VE. Radioprotective effect of the Barbados Cherry (Malpighia glabra L.) against radiopharmaceutical iodine-131 in Wistar rats in vivo. BMC Complement Altern Med. 2014;14:41

27. Zhao S, Yang Y, Liu W, Xuan Z, Wu S, Yu S, Mei K, Huang Y, Zhang P, Cai J, $\mathrm{Ni}$ J, Zhao $Y$. Protective effect of hydrogen-rich saline against radiationinduced immune dysfunction. J Cell Mol Med. 2014;18:938-46.

28. Piao MJ, Kim KC, Chae S, Keum YS, Kim HS, Hyun JW. Protective Effect of Fisetin (3,7,3', $\mathbf{4}^{\prime}$-Tetrahydroxyflavone) against $\gamma$-Irradiation-Induced Oxidative Stress and Cell Damage. Biomol Ther (Seoul). 2013;21:210-5.

29. Ran $Y$, Wang $R$, Gao Q, Jia Q, Hasan M, Awan MUF, Tang B, Zhou R, Dong Y, Wang X, Li Q, Ma H, Deng Y, Qing H. Dragon's blood and its extracts attenuate radiation-induced oxidative stress in mice. J Radiat Res. 2014;55:699-706.

30. Rahman I, Kinnula VL, Gorbunova V, Yao H. SIRT1 as a therapeutic target in inflammaging of the pulmonary disease. Prev Med. 2012;54(SUPPL):S20-8.
31. Uhl M, Csernok A, Aydin S, Kreienberg R, Wiesmüller L, Gatz SA. Role of SIRT1 in homologous recombination. DNA Repair (Amst). 2010;9:383-93.

32. Jin X, Yi L, Chen ML, Chen CY, Chang H, Zhang T, Wang L, Zhu JD, Zhang QY, Mi MT. Delphinidin-3-Glucoside protects against oxidized low-density lipoprotein-induced mitochondrial dysfunction in vascular endothelial cells via the sodium-dependent glucose transporter SGLT1. PLoS One. 2013;8:e68617. doi:10.1371/journal.pone.0068617. Print 2013.

\section{Submit your next manuscript to BioMed Central and we will help you at every step:}

- We accept pre-submission inquiries

- Our selector tool helps you to find the most relevant journal

- We provide round the clock customer support

- Convenient online submission

- Thorough peer review

- Inclusion in PubMed and all major indexing services

- Maximum visibility for your research

Submit your manuscript at www.biomedcentral.com/submit 